EWANGELINA SKALIŃSKA

\title{
SYBERYJSKA PERSPEKTYWA DROGI DO ROSJI MICKIEWICZA. O OBECNOŚCI (?) SACRUM W POLSKICH I ROSYJSKICH ODCZYTANIACH UTWORU
}

Mickiewiczowska Droga do Rosji (obok fragmentów tzw. sceny więziennej III cz. Dziadów) pozostaje w pierwszej połowie XIX wieku chyba najważniejszym tekstem literackim (a szerzej jeszcze) tekstem kultury, który definiuje polskie wyobrażenia zbiorowe nie tylko na temat Rosji jako takiej, ale przede wszystkim - Syberii czy Sybiru. Naturalnie, ani okoliczności „geopoetyckie”, ani biografia Mickiewicza nie tworzą przesłanek logicznych, by Drogę do Rosji traktować jako opis drogi „na Sybir”. Niemniej na takiej właśnie recepcji inicjalnego wiersza Ustępu zaważył najpewniej argument emocjonalny jego odbiorców, który kazał w latach późniejszych - mimo ustaleń badawczych Tretiaka, Kallenbacha czy Kleinera - traktować zesłanie Mickiewicza do Petersburga, Moskwy i Odessy jako „zesłanie w mityczną głąb Rosji”"2.

\footnotetext{
${ }^{1}$ Osobną kwestią jest, naturalnie, obecność w kulturze polskiej I połowy XIX wieku poematu Słowackiego Anhelli. I o ile jego wartość artystyczna była przez współczesnych mu twórców szacowana bardzo wysoko, o tyle sądzić można, że polską wyobraźnię zbiorową znacznie mocniej ukształtowały napisane wcześniej i w znacznie większym stopniu „realistyczne” Dziady Mickiewicza. Na temat recepcji Anhellego zob. np. Włodzimierz Toruń, Syberia Słowackiego. Próba tematologicznej syntezy, w: Syberyjskie przestrzenie intymne, red. Małgorzata Król, Małgorzata Łukaszuk, Lublin 2016.

${ }^{2}$ Szczegóły podróży Mickiewicza z Wilna do Petersburga ciągle jeszcze pozostają nie do końca jasne. Można, chyba, wspomnieć jedynie o tym, że droga z Wilna do
} 
Jednocześnie w omawianym tekście autora Dziadów pojawia się aż nadto wiele sygnałów (słów-kluczy) pozwalających na stworzenie dodatkowej warstwy odczytania pierwszego fragmentu Ustępu, sugerujących, że Mickiewiczowska droga do Rosji w polskiej wyobraźni zbiorowej musi łączyć się z obrazem drogi zesłańców „pędzonych na Sybir”. Pojawiające się już w pierwszych wersach Ustępu: „śnieg”, „dzika kraina”, „lot kibitki”, czasownik „zginąć”, wyraźnie tworzą przestrzeń polskiego "tekstu syberyjskiego"

Nie dziwi więc, że Zofia Trojanowicz, autorka najważniejszej do dziś antologii „polskiego Sybiru”, umieszcza na początku swojej książki właśnie fragmenty z III cz. Dziadów Mickiewicza.

Ciekawe, że narracja Trojanowicz wyraźnie sugeruje możliwość odczytywania Drogi do Rosji jako opisu pierwszego kręgu piekieł:

Skojarzenie Sybiru z zejściem w podziemia piekieł pojawiło się w twórczości Mickiewicza po raz pierwszy 12 października 1825 roku, we wczesnych godzinach rannych. Był piątek i właśnie wywożono na zesłanie Tomasza Zana, Adama Suzina, Jana Czeczota. Żegnano się w gronie przyjaciół, Mickiewicz w napięciu improwizował. [...] A myśl ta [zawarta w improwizacji] wydobywała podobieństwo między losem zesłanych filomatów i losem Chrystusa, między ich piątkiem i Jego Wielkim Piątkiem, między ich martyrologią i Jego męczeństwem. [...]

W świetle nauki Kościoła piekło, do którego zstąpił Chrystus, nie było miejscem wiecznej kaźni potępieńców, piekłem właściwym; było szeolem, otchłanią, miejscem przeznaczenia ludzkości przez grzech Adama odepchniętej od Boga. [...] O piekle, do którego zstąpił

Petersburga prowadziła wówczas przez Rygę i że odbywał poeta tę drogę wczesną jesienią w najpewniej całkiem znośnych warunkach, wielokrotnie bardziej korzystnych niż stało się to udziałem Tomasza Zana, Adama Suzina i Jana Czeczota.

${ }_{3}$ Rzecz interesująca i warta odnotowania, że już w znacznie wcześniejszym tekście dramatycznym, pochodzącym z przełomu wieku XVIII i XIX, pojawia się ten sam zestaw pojęć kluczowych, tworzących aurę literacką przestrzeni zesłańczej. Chodzi o wczesny dramat Kotzebuego Herr von Kotzebue in Sibirien (Lipsk 1802). Więcej na ten temat zob. Piotr Mitzner, Autor, zesłaniec i tłumacz. Wokół Kotzebuego, „Pamiętnik Teatralny” 2010, z. 1-2. 
Chrystus, pisał również Dante, umieszczając je w pierwszym kręgu swojego piekła ${ }^{4}$.

Mickiewiczowski początek Ustępu do III cz. Dziadów - Droga do Rosji - odczytywana jako droga na Sybir - staje się w tej optyce wędrówką przez pierwszy krąg piekła. A ten pierwszy krąg jest zamieszkany przede wszystkim przez „ludzi z rozrosłymi barki”, przez ludzi jeszcze (w pewien sposób) niezaistniałych, przypominających pod tym względem dusze dzieci, które nie zostały na czas ochrzczone. Przestrzeń pozbawiona pierwiastka sakralnego zawiera - jednocześnie - potencjał, by dojrzeć do sacrum albo - przeciwnie - podporządkować się złus.

Otwartość tej „niezaistniałej” jeszcze krainy i jej mieszkańców łączy się z refleksją Eliadego na temat sacrum rzeczywistości ludzkiej:

Stwierdziliśmy, że człowiek religijny żyje w „otwartym” świecie, że jego istnienie jest «otwarte» ku światu. Człowiek religijny jest więc otwarty na nieskończony szereg przeżyć „kosmicznych”. Są one zawsze religijne, świat jest bowiem święty ${ }^{6}$.

Naturalnie, w tym kontekście świadomość „człowieka religijnego" należy przypisać narratorowi Ustępu. To właśnie jego spojrzenie, kształtowane przez elementy (najostrożniej rzecz ujmując) „religijnego światoodczucia” przestrzeni Rosji, nadaje potencjalnej

\footnotetext{
${ }^{4}$ Zofia Trojanowicz, «Jej dzieje na Sybirze...», w: tejże, Sybir romantyków, w opracowaniu materiałów wspomnieniowych uczestniczył Jerzy Fiećko, Kraków 1992, S.102-103.

${ }^{5}$ Należy w tym miejscu odnotować, że Wiktor Weintraub odczytywał analizowane tu fragmenty Drogi do Rosji w perspektywie wyłącznie satyry politycznej. Badacz ten pisał: „Nie znaleźć w Ustępie tej jedynej w swoim rodzaju atmosfery [podniosłości i profetyzmu z części dramatycznej Dziadów drezdeńskich]. Pisał go poeta z pasją. Ale pasja to nade wszystko doczesnego, politycznego charakteru". (Wiktor Weintraub, «Ustęp» a profecja, w: tegoż, Poeta i prorok. Rzecz o profetyzmie Mickiewicza, Warszawa 1982, s. 254.

${ }^{6}$ Mircea Eliade, Egzystencja człowieka i uświęcenie życia, w: tegoż, Sacrum i profanum. O istocie religijności, tłum. Robert Reszke, Warszawa 1999, s. 139.
} 
religijności chłopstwu, zamieszkującemu przestrzeń między tzw. Inflantami Północnymi a Petersburgiem, czyli stolicą antychrysta?.

Obecność szeroko i różnorodnie rozumianego sacrum jest więc jedną z najważniejszych tradycji interpretacyjnych, łączących wypowiedzi więźniów z tzw. sceny więziennej III cz. Dziadów i fragmenty Ustępu.

Istotne, że właśnie Ustęp stał się jednym z najczęściej czytanych i komentowanych przez Rosjan tekstów Mickiewicza. Tyle że uwaga czytelnika rosyjskiego (przede wszystkim w wieku XIX) skupiała się raczej na fragmentach bezpośrednio opisujących Petersburg albo okoliczności wylania Newy czy też na zamykającym całość wierszu Do przyjaciół Moskali. Rzecz charakterystyczna, że obecność pierwiastków sakralnych w Drodze do Rosji niemal całkowicie umknęła rosyjskiej recepcji Ustępu i osobom podejmującym trud przełożenia tego utworu na język rosyjski.

Pierwsze rosyjskie tłumaczenia fragmentów Ustępu pojawiają się w rozprawie Aleksandra Gilfierdinga Rosja i słowiańszczyzna z 1868 roku. Mickiewiczowski fragment posłużył tu autorowi jako przykład nieodpowiedniego (powierzchownego i błędnego) stosunku Polaków (i w ogóle Słowian zachodnich) do Rosji i zamieszkującego ją ludu. Ten rosyjski słowianofil zamieszcza w Rosji i słowiańszczyźnie prozatorskie tłumaczenie fragmentów Drogi, ukazujących Rosję i jej mieszkańców jako byty jeszcze nieukształtowane, jako rzeczywistość geograficzną i ludzką pozbawioną jeszcze odniesienia do jakiejkolwiek aksjologii. Rzecz niezmiernie ciekawa, że Rosjanin rozpoczyna swój cytat z Mickiewicza od wersu: „Kraina pusta, biała i otwarta”, pomijając całkowitym milczeniem fragmenty wcześniejsze, w pewien

\footnotetext{
7 Traktowanie Petersburga jako stolicy szatana albo antychrysta, fałszywego proroka jest wyraźnie widoczne w dalszych fragmentach Ustępu. Warto natomiast wspomnieć przede wszystkim o rosyjskiej optyce spojrzenia mityczno-mitologicznego na założenie Petersburga i znaczenie Północnej Stolicy w dziejach Rosji jako miasta niszczącego narrację o Moskwie jako Trzecim Rzymie, a więc miasta szatańskiego. Można sądzić, że Mickiewicz dobrze zapoznał się z tym wymiarem narracji petersburskiej (a zwłaszcza interpretacją powodzi z roku 1824) w trakcie swojego pobytu w Petersburgu i w Moskwie.
} 
sposób utożsamiające drogę do Rosji ze szlakiem prowadzącym na Sybir. Taki dobór cytatów da się wytłumaczyć zapewne ideologicznym zapleczem autora, który chciałby przede wszystkim ukazać postawę Mickiewicza jako przykład ostentacyjnego lekceważenia kulturotwórczej i cywilizacyjnej roli Imperium Rosyjskiego. We fragmencie Rosji i słowiańszczyzny, bezpośrednio poprzedzającym cytaty z Mickiewicza, czytamy:

Czy w tych przykładach nie odnajdujemy potwierdzenia mojej myśli, że wśród przejawów współczesnej Rosji zachodni Słowianie lekceważą [...] jej stronę polityczną?

$[\ldots]$

Z jakąż miłością zwracają się oni [Słowianie zachodni] do pomników swojej dawno minionej niepodległości politycznej - do pomników, które na każdym kroku wskazują na ich niegdyś istniejący ustrój. I nie chcą zestawić tych świadectw martwej starożytności z żywym organizmem, z tym, co istnieje w narodzie rosyjskim ${ }^{8}$.

Mimo wyraźnie niechętnego stosunku do postawy politycznej Mickiewicza i szkód, jakie zdaniem Gilfierdinga polski poeta wyrządził Rosji, pierwsze znane dziś tłumaczenie fragmentów Ustępu pod wieloma względami może posłużyć jako przykład rzetelnej pracy translatorskiej. Ta okoliczność zapewne pozostaje w ścisłym związku z językoznawczymi zainteresowaniami Gilfierdinga. Trzeba jednak stwierdzić, że w tłumaczeniu tym zupełnie zatracona została szczególna aura Mickiewiczowskiej narracji, wyraźnie łącząca tłumaczony fragment $\mathrm{z}$ najważniejszymi pod względem ideowym fragmentami cz. III Dziadów. Pod piórem Gilfierdinga „ofiara” (z wersu „Że trofeami świata są: ofiary?”) traci swój religijny, eschatologiczny charakter i zamienia się w coś w rodzaju znanego w polszczyźnie „poświęcenia” (choć tłumaczenie pozostaje tu wierne: ofiara - жертва). Do podobnego przesunięcia semantycznego, wynikającego najprawdopodobniej $\mathrm{z}$ pozbawienia tłumaczonego fragmentu kontekstu macierzystego,

\footnotetext{
${ }^{8}$ Aleksandr Gilfierding, Rossija i sławianstwo, Moskwa 2009, s. 150. Tu i dalej-
} tłumaczenie moje: E.S. 
dochodzi w przypadku końcowych wersów omawianej strofy. Mickiewiczowskiemu:

Czyli też Boga nieprzyjaciel stary Przyjdzie i w księdze tej wyryje mieczem, Że ród człowieczy ma być w więzy kuty, Że trofeami ludzkości są: knuty??

(s. 268)

odpowiada rosyjskie:

Или же придет старый соперник Бога и в книге той вырежет мечем, что племя людское должно быть ковано в узы, что трофеи человечества - кнуты? ${ }^{10}$

Określenie „соперник Бога” z powodzeniem da się odczytać jako „szatan”. Tyle że - chociaż jest ono w pełni dla Rosjanina czytelne, to jednak nie mieści się w konwencji językowej mówienia o szatanie. Bo też po rosyjsku „szatan” to nie jest „соперник Бога” (czyli 'rywal'), ale - „враг” ('wróg'). Takie jednostkowe przesunięcie wobec uzusu językowego prowadzi ostatecznie do kolejnej (tym razem może nieco mniej wyraźnej) desakralizacji tekstu źródłowego.

W dalszych fragmentach swojego wywodu Gilfierding stwierdza:

Naród rosyjski istnieje dla nich [dla Polaków] jedynie jako masa nieokrzesanych „mużyków” (słowo to zostało przez nich przejęte z zabarwieniem negatywnym).

[...]

Że ta masa „mużyków-barbarzyńców”, obecnie uwalnianych, może mieć własne znaczenie w historii nie tylko jako surowa materia, ale jako siła moralna, to wszystko nawet się nie śniło Słowianom zachodnim. Niewątpliwie ich rozumienie Rosji i narodu rosyjskiego po

\footnotetext{
9 Wszystkie cytaty z Ustępu Mickiewicza podaję za wydaniem: Adam Mickiewicz, Dzieła, t. III: Utwory dramatyczne, komitet redakcyjny: Julian Krzyżanowski, Stanisław Pigoń, Leon Płoszewski, Henryk Wolpe, Kazimierz Wyka, Warszawa 1955. Bezpośrednio pod tekstem cytatu, w nawiasie, numer strony.

10 Aleksandr Gilfierding, dz.cyt., s. 152.
} 
części kształtują Polacy zarówno przez swoje wypowiedzi, jak i przez to wszystko, co drukuje na nasz temat emigracja ${ }^{11}$.

Przykładem tak niesprawiedliwego potraktowania chłopstwa rosyjskiego miał się stać, rzecz jasna, następujący fragment z Mickiewicza:

Ciało tych ludzi, jak gruba tkanica,

W której zimuje dusza gąsienica,

Nim sobie piersi do lotu wybrobi,

Skrzydła wyprzędzie, wytcze i ozdobi;

Ale gdy słońce wolności zaświeci,

Jakiż z powłoki tej owad wyleci?

Czy motyl jasny wzniesie się nad ziemię,

Czy ćma wypadnie, brudne nocy plemię?

(s. 269-270)

któremu sekunduje rosyjskie:

Тело этих людей, как грубая ткань, в которой зимует душа-гусеница, пока не расправит себе грудь для полету, пока не спрядет, не «выткет» и разукрасит себе крылья. Но когда засияет солнце свободы, какая из этого чехла вылетит бабочка? Светлый ли мотылек вознесется над землею или вылетит грязная моль, исчадие ночи ${ }^{12}$.

W zacytowanym przed chwilą fragmencie tłumaczenia z Mickiewicza dochodzi co najmniej do dwóch niezwykle frapujących rozbieżności pomiędzy oryginałem a przekładem. Pierwsza $z$ nich dotyczy najwyraźniej niezauważonego przez tłumacza kontekstu religijnego (szerzej - mistycznego) obrazu „duszy-gąsienicy”. 'Gąsienica', 'larwa motyla' czy najlepiej znany z późnej twórczości Mickiewicza 'jedwabnik' są wszak jeszcze wywodzącym się z antyku symbolem przemiany duchowej, który (w kręgu mistyki katolickiej)

11 Tamże, s. 151.

12 Tamże, s. 152. 
został najmocniej wykorzystany w Twierdzy wewnętrznej św. Teresy z Ávilii ${ }^{13}$. W języku rosyjskim i w tradycji prawosławnej określenie „dusza-gąsienica” nie niesie właściwie żadnych treści symbolicznych, może być co najwyżej rozpatrywane jako rodzaj metafory stadium rozwojowego samoświadomości. Autor tłumaczenia nie próbuje nadać temu zwrotowi dodatkowych treści, co wyraźnie świadczy o kolejnym, tym razem niezamierzonym i właściwie rzecz biorąc nieprzystającym do naczelnych tez Gilfierdinga procesie pozbawiania tekstu polskiego jego wymiaru sakralnego.

Druga rozbieżność wiąże się z wyraźnym przerysowaniem, mocnym spotęgowaniem jakości duchowo negatywnych w ostatnim wersie tłumaczonego fragmentu. W miejsce Mickiewiczowskiego „ćma [...] brudne nocy plemię" mamy (w tłumaczeniu filologicznym) 'brudna ćma, pomiot nocy'. Rosyjskie określenie 'исчадие' (zgodnie ze słownikiem Dala) należałoby oddać jako 'bękart', a zgodnie z tradycją prawosławną jako 'diabelski pomiot'. Tak więc z jednej strony brak ekwiwalentu kulturowego, a $\mathrm{z}$ drugiej jego nadmierne podkreślenie doprowadziły ostatecznie do sytuacji poniekąd paradoksalnej. Przyszłość narodu rosyjskiego (jak chcieliby słowianofile) albo (w optyce Mickiewicza) chłopstwa z terenów należących do ówczesnego Imperium Rosyjskiego dla narratora Ustępu pozostaje kwestią otwartą, niedającą się jeszcze rozstrzygnąć. Natomiast Gilfierding odczytuje Mickiewiczowską narrację w barwach znacznie ciemniejszych, sugerujących ostatecznie poddanie się moskiewskiego chłopstwa mocy zła.

Zupełnie inna pozycja ideologiczna stała się punktem wyjścia dla kolejnego tłumacza Mickiewiczowskiej Drogi do Rosji. Osiem pierwszych wersów tłumaczenia, opublikowanego w 1929 roku, wyszło spod pióra pisarza i tłumacza radzieckiego, Anatolija Wingradowa i stanowi przykład klasycznej, poprawnej sztuki translatorskiej.

${ }_{13}$ Zob. Dorothea Forstner, Świat symboliki chrześcijańskiej, tłum. Wanda Zakrzewska, Paweł Pachciarek, Ryszard Turzyński, Warszawa 1990, oraz: Grzegorz Igliński, Z Mickiewiczowskiego bestiariusza. Owady i robaki w «Dziadach», „Wiek XIX. Rocznik Towarzystwa Literackiego im. Adama Mickiewicza" 2016, Rok IX (LI). 
Natomiast dalszą część Ustępu przetłumaczył Siergiej Sołowjow, którego osoba jest szczególnie interesująca i wymaga przybliżenia. Siergiej Sołowjow (1885-1942), spowinowacony z Aleksandrem Błokiem, a przede wszystkim spokrewniony z Władimidrem Sołowjowem, debiutował jako poeta-symbolista. W rok po wybuchu I wojny światowej Sołowjow wstąpił do Moskiewskiej Akademii Duchownej, a następnie przyjął prawosławne święcenia kapłańskie. W roku 1920 przeniósł się do wspólnoty unickiej, a kilka lat później - katolickiej. W roku 1931 zostaje aresztowany jako podejrzany w sprawie „wspólnoty katolików rosyjskich”, po wpływem więzienia i przesłuchań zrzeka się godności kapłańskiej. Zwolniony z aresztu w tym samym roku, zapada na chorobę psychiczną i umiera w 1942 w szpitalu psychiatrycznym w Kazaniu w trakcie ewakuacji ludności cywilnej z terenów zagrożonych inwazją wojsk niemieckich.

Tak więc drugi rosyjski tłumacz Drogi do Rosji jest księdzem katolickim rosyjskiego pochodzenia, który w pełni dobrowolnie (i, co oczywiste, wbrew oczekiwaniom władz radzieckich) wybiera nie tylko stan duchowny, ale też łaciński, zachodni obrządek religijny. Naturalną koleją rzeczy rodzi się więc pytanie o obecność pierwiastka sakralnego w radzieckim tłumaczeniu Mickiewicza, opracowanym przez moskiewskiego księdza katolickiego. Najciekawiej pod tym względem prezentuje się fragment inicjalnego wiersza Ustępu, w którym opisuje polski poeta „rosyjskich mużyków” (wedle określenia Gilfierdinga).

Jak powiedziano wcześniej, Mickiewicz przede wszystkim akcentuje „bezdziejowość” i potencjalność spotkanej ludności. Jest ona dzika i nieprzebudzona jeszcze do człowieczeństwa niczym „zwierzęta i drzewa północy". Natomiast u Sołowjowa już na samym początku dochodzi do wyraźnej konkretyzacji Mickiewiczowskiego obrazu i jego pogłębienia:

\footnotetext{
Московских крестьян наблюдаю при встрече:

У всех них широкие груди и плечи;

Подобно зверям полуночной дубровы,

Полны они силы, могучи, здоровы.

Но эти пустые, открытые лики,
} 


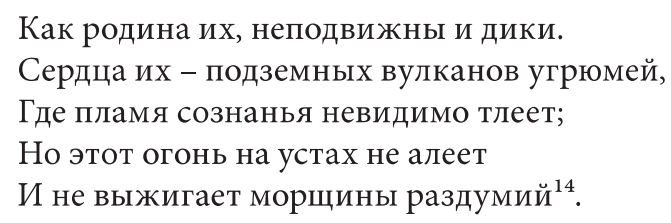

W tłumaczeniu rosyjskim „ludzie” zostają dookreśleni jako „chłopstwo moskiewskie”. Można też odnieść wrażenie, że Sołowjow, opisując po rosyjsku fizyczną potęgę i duchową martwotę tych ludzi, inspiruje się przede wszystkim późniejszym obrazem Mickiewiczowskim, zawartym w Przeglądzie wojska; obrazem ,trupa na pół chłopskiego, na poły wojskowego". Kolejną ciekawą cechą konkretyzacji na poziomie obrazowania poetyckiego, podjętej przez rosyjskiego tłumacza, jest przypisanie chłopstwu moskiewskiemu dodatkowych wartości duchowych, których nie zawiera tekst oryginalny. U Mickiewicza czytamy:

I z ich serc, jako wulkanów podziemnych, Jeszcze nie przeszedł ogień aż do twarzy, Ani się w ustach rozognionych żarzy, Ani zastyga w czoła zmarszczkach ciemnych.

Natomiast Sołowjow (w tłumaczeniu filologicznym) pisze: „Ich serca są bardziej ponure od podziemnych wulkanów,/ W których tli się niewidzialny z zewnątrz ognik świadomości;/ Ale ten ognik nie wykwita czerwienią na ustach/I nie wypala zmarszczek świadomości”. Mickiewiczowski „ogień”, który w tym kontekście należałoby rozumieć zapewne jako po prostu zapał psychiczny, ruch myśli, zyskuje w wersji rosyjskiej dookreślenie w postaci „świadomości”, z kontekstu tłumaczenia można wnioskować, że świadomość ta ma pewien wymiar religijny, że łączy się ona w obrazowaniu Sołowjowa-Mickiewicza z płomieniem Ducha Świętego.

W tym nazbyt może skrótowym przeglądzie rosyjskich rozwiązań translatorskich koniecznie trzeba jeszcze zwrócić uwagę na ostatnie ze

${ }_{14}$ Adam Mickiewicz, Izbrannyje proizwiedienija. Pieriewody ruskich poetow, Moskwa-Leningrad 1929, s. 249-250. 
znanych mi tłumaczeń, stworzone i opublikowane w jeszcze innych warunkach historycznych i politycznych.

Po odwilży roku 1955 powstaje w Związku Sowieckim (równolegle do polskiego wydania jubileuszowego dzieł Mickiewicza) najobszerniejsza edycja rosyjska dzieł autora Dziadów. W dwutomowym wydaniu Mickiewicza z tego roku nie brakuje, rzecz jasna, także pełnego tłumaczenia Dziadów (zarówno wileńsko-kowieńskich, jak i drezdeńskich), zakończonego przekładem Ustępu.

Autorem tego tłumaczenia jest Wilhelm Lewik, który zarówno w Rosji Sowieckiej, jak i w Rosji współczesnej postrzegany jest jako jeden z największych mistrzów przekładu poetyckiego. Oprócz tłumaczeń Mickiewicza opublikował także przekłady Szekspira, Byrona, Heinego, La Fontaine’a, Goethego i wielu innych.

Należy jednak dokładnie zdać sobie sprawę z warunków wydawniczych i, co ważniejsze, politycznych, w jakich ukazał się omawiany przeze mnie przekład. O ile terror i jednoczesny zamęt lat 30. w Rosji Sowieckiej, a także autorytet Winogradowa sprawiły, że ukazał się drukiem wyraźnie nieprzystający do linii partyjnej (przynajmniej pod interesującymi mnie względami) przekład Sołowjowa, o tyle tym razem sytuacja wydawców Mickiewicza i jego tłumaczy okazała się nieco bardziej skomplikowana.

Rzeczą niewymagającą dodatkowego komentarza są, naturalnie, te fragmenty Ustępu, w których pojawia się negatywny opis cara Mikołaja I czy też los biednego, zamarzniętego na śmierć chłopa, podporządkowanego terrorowi carskiemu i społecznemu. Z podobnym dystansem można też było bez trudu potraktować „dziwactwa” Oleszkiewicza czy też podkreślić pozytywny dla socjalizmu sowieckiego wymiar działalności dekabrystów.

Inną, o wiele trudniejszą w tym świetle sprawą stawały się wyraźnie sakralizowane przez Mickiewicza początkowe fragmenty Drogi do Rosji, które skutkiem kilku przesunięć czy nawet przerysowań translatorskich Sołowjowa zyskały dodatkowy, bliższy może wrażliwości rosyjskiej wymiar.

Pierwszą dość interesującą i wieloznaczną informacją jest fakt, że Lewik zastąpił pojawiającą się już w pierwszym wersie Mickiewicza 
„kibitkę” określeniem „wózek” («возок»), znaczący mniej więcej tyle, co wóz na płozach, przeznaczony do jazdy zimą, dodatkowo ocieplany, m.in. dzięki zmniejszonym oknom. Wózki takie wyszły z użycia w Rosji mniej więcej w połowie XIX wieku. Na dodatek zimowa jazda właśnie na płozach, a nie na kołach traktowana była jako bardziej luksusowa, a więc przeznaczona dla ważniejszych i bardziej zamożnych obywateli.

Jednocześnie Mickiewiczowska obserwacja (nieco zlekceważona przez wcześniejszych tłumaczy tego tekstu):

I oczy moje jako dwa sokoły

Nad oceanem nieprzejrzanym krążą,

Porwane burzą do lądu nie zdążą,

A widzą obce pod sobą żywioły,

Nie mają kędy spocząć, skrzydła zwiną,

W dół patrzą, czując, że tam muszą zginąć.

(s. 267)

wyraźnie akcentuje sytuację poniekąd odwrotną niż „hiperrealistyczne" postrzeganie rzeczywistości, znane chociażby ze Stepów akermańskich. Tutaj - porównując własne możliwości wizualne do wzroku sokoła - Mickiewicz jednak kapituluje, zdradzając swoją bezradność wzrokową. Następnie, nieco paradoksalnie, zaczyna opisywać to, czego w zamieci śnieżnej, we mgle nie sposób było przecież zobaczyć.

W tekście rosyjskim czytamy:

По диким пространством, по снежной равнине

Летит мой возок, точно ветер в пустыне.

И взор мой вперился в метельный туман, -

Как сокол в пустынную даль залетевший,

Застигнутый бурей, к земле не поспевший,

Глядит как бушует под ним океан,

Не знает, где крылья на отдых он сложит,

И чует, что смерть отвратить он не может ${ }^{15}$.

15 Adam Mickiewicz, Izbrannyje proizwiedienija $w$ dwuch tomach, t. II, Moskwa 1955, s. 239. 
Zbigniew Sudolski, opisując niezwykle skrótowo szczegóły początkowych fragmentów podróży Mickiewicza $z$ Wilna do Petersburga (przypomnę, że szlak ten prowadził przez Rygę), pisze:

Trudno z powodu braku szczegółów odtworzyć tę dość egzotyczną podróż. Wiadomo jedynie, iż 1/13 listopada 1824 roku stanęli nasi zesłańcy w Rydze. Jakieś reminiscencje z tej podróży odezwały się później we fragmentach Ustępu do części III Dziadów [... $]^{16}$.

Mniejsza może w tym momencie o szczegóły biograficzne, ważne natomiast, że już w pierwszym wersie analizowanego przekładu jedno z podstawowych - zarówno dla Polaków, jak i Rosjan - kluczowych określeń, związanych z masowymi wywózkami na Syberię w wieku XIX, zostaje przez tłumacza - jak można się domyślać - przede wszystkim ze względów cenzuralnych, pominięte.

Wypada jeszcze w największym skrócie przyjrzeć się obecności bądź nieobecności znaków Mickiewiczowskiego sacrum w tłumaczeniu z 1955 roku.

Podobnie, jak miało to miejsce w przypadku zastąpienia 'kibitki' bardziej neutralnym, a nawet luksusowym 'wózkiem', Lewik dokonuje w swojej wersji Drogi do Rosji jeszcze kilku innych znaczących przesunięć semantycznych.

Brak, cechujący przestrzeń przemierzaną przez narratora Ustępu, zostaje przez tłumacza uzasadniony „zimnem”, ono to miało w wersji translatorskiej z roku 1955 uzasadniać „obumarcie” rozległych połaci Imperium Rosyjskiego. Więcej nawet, zgodnie z założeniami światopoglądowymi wydawcy, Mickiewiczowska „ziemia [...] jak gdyby wczoraj wieczorem stworzona” - „powstała wczoraj” („Как будто вчера лишь возникла планета”).

Tego rodzaju przykłady można by mnożyć...

Rosyjska recepcja Mickiewiczowskiej Drogi do Rosji musiała z założenia narzucać wiele problemów translatorskich, wynikających - co oczywiste - z mocnego albo to światopoglądowego, albo też politycznego zaangażowania tłumaczy.

${ }^{16}$ Zbigniew Sudolski, Mickiewicz. Opowieść biograficzna, Warszawa 2004, s 161. 
Zgodnie z sądem jednego z największych współczesnych autorytetów w dziedzinie przekładoznawstwa, Krzysztofa Hejwowskiego, tłumaczenie zawsze pozostaje swego rodzaju iluzją, chociaż:

Tłumaczenie jest szczególną formą komunikacji, bo pośredniczy między ludźmi z różnych kultur mówiących różnymi językami. W przypadku tłumaczeń literackich (i nie tylko) bardzo często odbiorcy przekładu nie byli „planowanymi” odbiorcami tekstu $[\ldots]^{17}$.

Nie wiem tylko, czy zdanie to jest w pełni prawdziwe w odniesieniu do twórczości Mickiewicza i czy właśnie Rosjanie (obok Polaków) nie mieli być zdaniem autora Dziadów najważniejszym odbiorcą jego wizji Imperium Rosyjskiego.

\section{Summary \\ Ewangelina Skalińska, “A Syberian Perpective in Mickiewicz's «Droga do Rosji» («The Road to Russia»). On the Presence of the Sacred in Polish and Russian Interpretations of the Poem"}

This paper, using the tools of Translation Studies, analyses the chosen translations of the first fragment of Mickiewicz's introduction to Dziady cz. III (The Forefathers' Eve, Part III) in the context of neutralization of its Christian issues. This text, since the nineteenth century, has been manipulated on by Russian translators, in such ways which have allowed them to stress current political and philosophical issues.

Ewangelina Skalińska (Uniwersytet Kardynała Stefana Wyszyńskiego), dr - adiunkt w Katedrze Badań nad Romantyzmem i Twórczością C. Norwida. Autorka książki Norwid - Dostojewski. Zbliżenia i rekonstrukcje (Warszawa 2014).

${ }^{17}$ Krzysztof Hejwowski, Iluzja przekładu. Przekładoznawstwo w ujęciu konstruktywnym, Katowice 2015, s. 9-10. 